\title{
O jubileuszu Uniwersytetu Łódzkiego
}

Z dawna już słychać było o przygotowaniach do jubileuszu siedemdziesięciolecia Uniwersytetu Łódzkiego. Umawialiśmy się na spotkania z kolegami i wyrabialiśmy karty absolwenta. 15 maja 2015 roku w tygodniku „Kocham Łódź” ukazał się obszerny artykuł Anny Gronczewskiej informujący o siedemdziesiątych urodzinach Uniwersytetu Łódzkiego. Duże zdjęcie pierwszego rektora prof. Tadeusza Kotarbińskiego, a obok sylwetki starego budynku „mat-fizchemu”, nowego wydziału fizyki, wspomnienia byłych studentów, profesorów, sympatyczne ciekawostki. Artykuł kończył się wyrazistą oceną polityczno-kadrową. „Ciężki czas dla Uniwersytetu Łódzkiego rozpoczął się w latach 1949_ 1950. Zaczął się wtedy nasilać stalinizm. Uczelnię opuścił prof. Tadeusz Kotarbiński. (...) Rektorem Uniwersytetu Łódzkiego był wówczas prof. Józef Chałasiński. Jak po latach twierdzili historycy, pogłębieniu kryzysu uczelni sprzyjały koncepcje profesora Chałasińskiego. Preferował on koncepcję stworzenia uczelni nawiązującej do rewolucyjnych tradycji Łodzi - wyjaśniali historycy. Jego model uniwersytetu robotniczego miasta podporządkowany był ideologii marksistowskiej i polityce ówczesnego rządu”. Skoro dziennikarka przypisała Chałasińskiemu niechlubną rolę w historii uniwersytetu, to jest on w jej tekście tylko profesorem socjologii, który objął funkcję rektora po „wybitnym filozofie” Tadeuszu Kotarbińskim, który na sztandarze uniwersytetu kazał umieścić hasło: prawda i wolność. „W 1952 roku miejsce profesora Chałasińskiego zajął wybitny socjolog prof. Jan Szczepański. Uniwersytet powoli zaczął przezwyciężać kryzys”. Zwięźle, wyraziście, niech łodzianie znają historię swojego uniwersytetu.

Więcej na ten temat przeczytamy w „Zarysie historii Uniwersytetu Łódzkiego 1945-2015” Wiesława Pusia, profesora historii i siedemnastego rektora Uniwersytetu Łódzkiego. Książka liczy blisko czterysta stron: I - Powstanie, rozwój i rozbudowa uczelni w latach 1945-2015; II - Wydziały i inne jednostki Uniwersytetu Łódzkiego; III - Życie społeczno-polityczne uczelni; IV - Rektorzy Uniwersytetu Łódzkiego w latach 1945-2015. Trzeci punkt pierwszego rozdziału ma tytuł: Klęska koncepcji „,socjalistycznego uniwersytetu robotniczego miasta”. Z sarkazmem przypomina prof. Puś pomysł rektora Chałasińskiego „zaproszenia na inaugurację nowego roku akademickiego 1949/1950 przedstawicieli łódzkich robotników. Uroczystość ta odbyła się 1 października 1949 roku o godz. 16 na wolnym powietrzu przy ul. Lindleya 5”. W dniu 3 października 1949 roku „odbyła się druga część inauguracji w auli uniwersytetu przeznaczona wyłącznie dla pracowników i studentów uczelni. Także w czasie tej uroczystości (...) rektor J. Chałasiński wygłosił płomienne przemówienie, odwołując się do przeobrażeń społecznych, gospodarczych i kulturalnych, które jego zdaniem były następstwem 
nowego socjalistycznego ustroju”. Zdaniem łódzkich historyków te inicjatywy rektora Chałasińskiego miały „iść na rękę władzom partyjnym”, a „okazało się jednak, że deklaracje Chałasińskiego były traktowane z dużą nieufnością a czasem i wrogością ze strony Komitetu Łódzkiego PZPR, jak również w ministerstwie".

Wygląda na to, że w 1949 roku, i dwóch następnych latach tylko Chałasiński chciał w Łodzi socjalistycznego uniwersytetu. Ten gigantyczny paradoks da się jednak wyjaśnić. Najpierw przypomnijmy, że obejmując funkcję rektora Uniwersytetu w 1949 roku Chałasiński był profesorem zwyczajnym i dyrektorem osobiście wznowionego Instytutu Socjologicznego. W swoim dorobku miał już takie książki jak: „Drogi awansu społecznego robotnika” - studium oparte na autobiografiach robotników (praca habilitacyjna napisana przez 27-letniego autora), po raz pierwszy użyty termin »awansu społecznego «, przeniesiony potem do nauk społecznych i języka potocznego; „Życiorys własny robotnika” - niezwykle pracochłonne i trudne redakcyjnie dokonanie; „Młode pokolenie chłopów. Procesy i zagadnienia kształtowania się warstwy chłopskiej w Polsce” - czterotomowe dzieło wydane tuż przed II wojną światową. To dziś klasyka socjologiczna w zakresie metody, bo materiałem źródłowym są autobiografie, ale też dlatego, że autorami tych biografii byli ludzie z nizin społecznych - proletariatu, jak to się mawiało $\mathrm{w}$ czasach rektorstwa prof. Chałasińskiego. Prace te w szerokiej perspektywie humanistycznej nawiązywały do myśli i dokonań społeczno-reformatorskich Stanisława Staszica, społecznego radykalizmu Ludwika Krzywickiego, aspiracji młodzieży wiejskiej przed wojną, ruchu ludowego i wiciowego, roli przywódców chłopskich, a Wincentego Witosa w szczególności. Centralnym problemem poznawczym a jednocześnie obywatelskim prof. Chałasińskiego był awans społeczny ludzi pracy fizycznej rozumiany jako wyzwalanie się z udręki biedy, ale też od myślenia, że podległość panom jest stanem normalnym i naturalnym. W przekraczaniu tego fizycznego i umysłowego zniewolenia, a w dalszej konsekwencji uzyskania podmiotowej roli w kulturze narodowej i w społeczeństwie obywatelskim miały i mają: szkoła, czytelnictwo, aktywność społecznikowska. Na ten temat są książki Chałasińskiego napisane też przed powołaniem Go na rektora UŁ: „Wychowanie w domu obcym jako instytucja społeczna” (doktorat obroniony w wieku 23 lat); „Antagonizm polsko-niemiecki w osadzie fabrycznej „Kopalnia« na Górnym Śląsku”; „Parafia i szkoła parafialna wśród emigracji polskiej w Ameryce”; „Szkoła w społeczeństwie amerykańskim”; „Społeczeństwo i wychowanie" - książka zawierająca wykłady Chałasińskiego w UŁ z socjologii wychowania w latach akademickich 1945/46 i 46/47. Dodajmy jeszcze wykład inauguracyjny w UŁ w 1946 roku „Społeczna genealogia inteligencji polskiej” - do dzisiaj najczęściej wymieniany wśród pozycji naukowych w powojennej socjologii polskiej.

Łódź była miastem, z którym najmocniej wiązała się biografia prof. Chałasińskiego. „Dzieje uniwersytetu - pisał Chałasiński w pamiętnikarskim wspomnieniu w tomie »Tranzytem przez Łódź« - od jego początków głęboko i mocno wiązały się z życiem i pracą naukową autora tego artykułu. W mieście tym i na tym właśnie uniwersytecie nie znalazł się przypadkowo. Z trzydziestu lat pracy 
uniwersyteckiej - licząc od docentury uzyskanej na Uniwersytecie Poznańskim w 1931 r. - minęło 25 lat pracy w łódzkim środowisku naukowym (1962). Zaczęła się ona w 1932 roku, gdy jako profesor socjologii na Wolnej Wszechnicy Polskiej dojeżdżał z Warszawy do Łodzi”.

Nowy rektor Uniwersytetu Łódzkiego - prof. Chałasiński, zapraszając na inaugurację roku akademickiego przedstawicieli łódzkich robotników, deklarował, że ta nowo powstała dostojna i szlachetna instytucja kultury narodowej utożsamia się z zasadniczą, przeważającą częścią społeczności tego miasta - robotnikami. To oczywiste nawiązanie do „Ziemi obiecanej” Stanisława Reymonta z optymistycznym przesłaniem, że nie ma sprzeczności między wysiłkiem fizycznym a kształceniem, doskonaleniem umysłowym i deklaracja, że ten uniwersytet, z tym rektorem weźmie aktywny udział w ostatecznym przełamaniu barier stanowych. Tak prof. Chałasiński wykorzystał czas radykalnych zmian społeczno-politycznych w naszym kraju. Kontynuował upowszechnianie oświaty i nauki ze zrozumieniem okoliczności i uwarunkowań, co nie powinno wywoływać zdumienia u historyka.

Profesor Chałasiński był sobą. Pisze o tym prof. Szczepański we wstępie do „Dzieł wybranych” Chałasińskiego. „Patrząc na bibliografię prac publikowanych w latach po roku 1927 uderzać musi przerażająca wręcz pracowitość Józefa Chałasińskiego. I dalej: „Chałasiński zwolennik lewicującego liberalizmu, urzeczony radykalnym ruchem młodzieży chłopskiej przed wojną, widzący i podkreślający wartości chłopskiej kultury i widzący wyraźnie ujemne strony pozostałości feudalizmu w życiu społeczeństwa przedwojennego” pozostał sobą. Oto fragment refleksji z 1964 roku ze wstępu do tomu „Awans pokolenia” z serii „Młode pokolenie wsi Polski Ludowej”: „Pisarz francuski Jean Paul Sartre (ur. w 1905 roku), którego filozoficzne kłopoty z problemami istnienia i nieistnienia uczyniły bardzo popularnym w stolicach współczesnego świata, swojej wydanej niedawno autobiografii dał tytuł »Les mots (Słowa)«. W tym tytule zawarta jest charakterystyka środowiska, które od wczesnego dzieciństwa kształtowało jego psychikę. »Na próżno - pisze Sartre - szukałbym w sobie skłębienia wspomnień i słodkiej bezrefleksyjności dzieciństwa wiejskiego. Nigdy nie kopałem ziemi i nie szukałem ptasich gniazd.... Moje książki były moimi ptakami i moimi gniazdami, moimi zwierzętami domowymi, moją stajnią i moją wsią«. Rozmaita bywa »wieś« dzieciństwa, w której formułują się zręby osobowości ludzkiej; czasem dominuje w niej książka, a nie ma ptaków, kiedy indziej są ptaki bez książki. Ludzie i zwierzęta, rzeczy i wydarzenia wchodzą do biografii człowieka w różny sposób. Koza i krowa w autobiografii Gandhiego to jest co innego niż piesek w biografii filozofa, który mu towarzysko asystuje w jego rannym spacerze. Gdybym za przykładem cytowanego filozofa francuskiego i jednocześnie mojego rówieśnika miał pisać podobny pamiętnik, to nie mógłbym w nim pominąc krowy. W mojej autobiografii związały się ze sobą nie tylko krowa i historia, ale także krowa i filozofia. Jako mały chłopiec pasłem krowę, gdy zaczynała się pierwsza wojna światowa i potem w różnych okolicznościach okresu wojny. Pasłem też krowy podczas II wojny światowej podczas powstania, gdy paliła się Warszawa... Wówczas to w mojej autobiografii spotkała się krowa z historią i filozofią życia, 
istnienia i nieistnienia, z silniejszym niż kiedykolwiek poczuciem zespolenia się bytu osobistego z bytem całego kraju”.

W tym samym czasie po zapoznaniu się z treścią tysięcy pamiętników młodego pokolenia, Chałasiński dochodzi do wniosku, że „specjalista od badań ankietowych czy od maszyn elektronowych z charakteru swojego zawodu nie jest dzisiaj bliższy inteligencji - w sensie zbiorowości o ogólnej kulturze humanistycznej - niż monter z elektrowni... Jeżeli zaś upodobanie do czytania i pisania wierszy uważać za należące do inteligenckich tradycji, to wśród pamiętnikarzy wiejskich, o których tu mowa - wśród rolników i gospodyń wiejskich - występuje ono częściej niż wśród uczonych z Warszawy”. Aby wyraźniej dostrzec postawę humanisty Chałasińskiego skonfrontujmy zacytowane oceny z fragmentem książki Rafała Ziemkiewicza „Michnikowszczyzna” z 2006 r. o ludziach awansu społecznego w PRL: „przeważnie wyszło toto z jakichś zapadłych wsi; z folwarcznych czworaków i bardzo biednych rodzin, niekiedy wręcz z marginesu społecznego i wszystko zawdzięczało Nowej Wierze”. W traktowaniu ludzi pracy fizycznej w kulturze narodowej podmiotowo i równorzędnie z innymi grupami społecznymi Chałasiński był konsekwentny i wyrazisty, ale nie odosobniony. Podobny pogląd znajdziemy w twórczości profesorów: F. Bujaka, S. Pigonia i u pisarza W. Myśliwskiego.

Okres Polski Ludowej w zakresie egalitaryzacji społeczeństwa i zadamawiania się ludu w kulturze narodowej jest wyjątkowy. Chałasiński obejmując funkcję rektora Uniwersytetu Łódzkiego, dostrzegał tę historyczną szansę, wspierał ją i przede wszystkim znakomicie zanalizował i udokumentował. Czytam i słucham w radio, że z książek Chałasińskiego korzystają: dziennikarz, reżyser, ksiądz nawet.

Skwapliwie przytaczana przez autora „Zarysu historii UŁ” nieufność władz partyjnych i administracyjnych miasta i resortu wobec inicjatyw rektora nie dziwią mnie zupełnie. Potwierdzają tylko, że Chałasiński nie wystawał pod gabinetami po akceptację swoich decyzji, a władze nie nadążały za rozmachem ideowym i naukowym Rektora. Przeczytajmy teraz jakie inne „prawdy historyczne” ustalił rektor Puś (historyk) o rektorze Chałasińskim (doktorze honoris causa Uniwersytetu Łódzkiego). „W okresie trzyletniej kadencji rektora J. Chałasińskiego zlikwidowano następujące kierunki na wydziale humanistycznym: filozofię, wszystkie neofilologie, poza rusycystyką, archeologię, etnografię, socjologię (jak wiadomo rektor był socjologiem), filologię klasyczną, historię sztuki” (s. 29). „Kolejnym ważnym problemem była sprawa odpływu wybitnych profesorów do Uniwersytetu Warszawskiego. Tak zwany exodus wielu uznanych uczonych rozpoczął się już w 1948 roku, ale jego apogeum przypadło na okres kadencji rektora J. Chałasińskiego” (s. 29). „Odpływ kadry profesorskiej z naszej Uczelni głównie do Warszawy trwał także w latach późniejszych, nigdy jednak nie przybrał takich rozmiarów jak w okresie kadencji rektora J. Chałasińskiego” (s. 30). „Ówczesne władze administracyjne oraz polityczne naszego miasta niezbyt przychylnie traktowały potrzeby Uniwersytetu Łódzkiego... Tymczasem rektor J. Chałasiński, mimo różnego rodzaju niepowodzeń w kontaktach z władzami miasta, często używał określenia, że UŁ jest dzieckiem robotniczej Łodzi”. „Niestety nie powiodły 
się próby rektora J. Szczepańskiego przywrócenia naboru na kierunki, które zostały zlikwidowane za kadencji rektora J. Chałasińskiego” (s. 34). „Rektor J. Szczepański unikał górnolotnych wypowiedzi o »socjalistycznym uniwersytecie robotniczej Łodzi« dzięki czemu zdecydowanie poprawił stosunki z władzami łódzkimi oraz z ministerstwem” (s. 33). „Generalna ocena rektora J. Chałasińskiego nie może być pozytywna” (s. 32).

Przypomnijmy przeto, że lata 1949-52 w Polsce (czyli lata kadencji rektora Chałasińskiego) były najtrudniejszymi dla całej humanistyki z Uniwersytetem Łódzkim włącznie. Tymczasem w „Zarysie historii UŁ” oceny Jego rektorowania dokonano tak, jakby przy pomocy liczb wykazać spadek dochodów w gospodarstwie rolnym w trzechleciu, nie wspominając, że w okresie ocenianym dwukrotnie było gradobicie i spadek cen na główny produkt o 300 procent, a akcentować nazwisko gospodarza.

To, że w tych niezwykle trudnych latach rektorem UŁ był prof. Chałasiński, wyraźnie i szczerze deklarujący się po stronie socjalistycznych przeobrażeń i współpracy z nową władzą, uchroniło Uniwersytet Łódzki przed jeszcze głębszą degradacją. To dzięki Chałasińskiemu UŁ „oskubywany” kadrowo, zniewolony doktrynalnie zakorzenił się w Łodzi, zaistniał w świadomości mieszkańców i panoramie miasta. „W odbudowie powojennej i kształtowaniu nauki w Polsce Ludowej zapisał się jako organizator szkolnictwa wyższego, którego działalność w Uniwersytecie Łódzkim promieniowała szeroko na cały kraj” - pisał prof. Jan Szczepański w „Polityce” nr 7 (luty 1980). Po lekturze „Zarysu...” mam prawo sądzić, że to dla pomysłu napisania, że Chałasiński przyczynił się do likwidacji swojej socjologii na swoim uniwersytecie autor nie napisał w ogóle, jak trudne były owe lata w całym kraju. Przecież wtedy niektórzy przyszli luminarze humanistyki walczyli z bronią w ręku z „bandami”, a inni usłużnie podpowiadali władzom nazwiska „burżuazyjnych” autorów przedwojennych. Chałasiński w owym czasie zaprosił robotników na inaugurację roku akademickiego i powiedział: to jest wasz uniwersytet, a parę lat później na procesie poznańskim - powołany przez obronę jako autorytet i ekspert - bronił robotników, uzasadniając ich racje i prawo do protestu. Chałasiński nie wyjechał ze swojej Łodzi. Usunięty został z Uniwersytetu w 1962 roku za śmiałą i samodzielną krytykę polityki władz wobec nauki.

Pozostaje jeszcze odnieść się do zarzutu przyczynienia się Chałasińskiego do wyjazdu uczonych z Łodzi. Posłużę się „Dziennikami z lat 1945-68” Jana Szczepańskiego - profesora socjologii, który po Chałasińskim objął funkcję rektora UŁ. Jest rok 1946.13.01. „Dzisiaj oficjalna i uroczysta inauguracja Uniwersytetu Łódzkiego z immatrykulacją i odczytem Chałasińskiego. Odczyt nie pozostanie bez konsekwencji, bo był śmiały, brillant”. 17.02. „Zjazd pedagogiczny ze świetnym odczytem Chałasińskiego i straszną falą bezdusznej gadaniny”. 3.03. „Chałasiński ustąpił z prorektorstwa i teraz będzie miał czas na ruszenie Instytutu. 14.07. „Pracy habilitacyjnej jeszcze nie napisałem, ale mam nadzieję habilitować się po wakacjach. Chałasiński chciał nas osadzić na katedrach: Ninę i mnie. Sprzeciwił się Kotarbiński: za młodzi. Ossowski przenosi się do Warszawy. Chałasiński został dziekanem... Z Chałasińskim stosunki ułożyły się dobrze”. 10.10. „Chałasiński wygłosił w Instytucie pierwszy po wakacjach odczyt pt. »Tworzenie 
legendy a naukowe zadania historii « ... odczyt był brillant. Ma pójść w »Myśli współczesnej«. Przewiduję kryzys i kłopoty. Odczyt był śmiały, ale miał punkty słabe”. 27.10. „Wieczorem było przyjęcie u Chałasińskich. Byli: Ossowscy, Serejscy, Śreniowscy, Nina i Kula, my i asystenci Instytutu. Było miło i wesoło. Chałasiński niewątpliwie staje się centrum i ośrodkiem ruchu umysłowego". 21.08. „Czasami myślę o zbliżającym się roku akademickim i myślę z niepokojem. Ossowski wyjedzie, Obrębskiego nie ma, Nina wyjeżdża, zostaje Chałasiński i ja dla wykładania w czterech uczelniach i prowadzenia seminarium, wydawania »Przeglądu«, prowadzenia różnych badań itp., wydania antologii robotniczej i Bóg wie czego jeszcze”. 23.09. „Dziś otrzymałem list z Wrocławia. Sprawa katedry socjologii we Wrocławiu zbliża się do rozstrzygnięcia. Zakomunikowałem to zupełnie nieoficjalnie Chałasińskiemu. Otóż dowiedziałem się, że Józiu bardzo chciałby mnie widzieć na katedrze po Ossowskim”. 4.11. „Chałasiński wysłał do Wrocławia swoje opinie. Nigdy chyba nie czytałem tak pochlebnej opinii o sobie... Chałasiński przestawia, zdaje się, Instytut na nową koncepcję - instytutu uniwersyteckiego w postaci własnej szkoły, wyhodowanej spośród studentów. Pomysł najlepszy”. Widzimy w tych zapiskach, że wyjazdy do Warszawy rozpoczęły się już w 1946 roku. Odbudowywana dynamicznie Warszawa i stołeczny uniwersytet były atrakcyjne. Ujawniane ambicje naukowe i przejawy rywalizacji potwierdzają wolę Chałasińskiego rozwijania własnej szkoły socjologicznej w ramach nieliberalnego, egalitarnego uniwersytetu. Nie widać zachowań destrukcyjnych, hamujących rozwój młodej uczelni. Przeciwnie, wielką troską Chałasińskiego było pogodzenie ludowości uniwersytetu z wysokim poziomem. Pod datą 29.12.1954 roku, już w czasie własnej kadencji rektorskiej, profesor Szczepański wspomina: „wizyta Chałasińskich i pracowników Instytutu. Chałasiński długo opowiadał o Paryżu, o konstelacji politycznej i wynikających stąd dla nauki u nas. W możliwość rychłej wojny nie wierzy, sądzi, że należy wykorzystać otwierające się możliwości współpracy z zagranicą wskutek przystąpienia Polski do UNESCO. Jego zdaniem trzeba: 1 . uczyć się pilnie języków - tak by móc swobodnie mówić i pisać, 2. rozpocząć u nas badania socjologiczne tych dziedzin, które budzą zainteresowanie międzynarodowych organizacji naukowych, przygotować się do wzięcia udziału w międzynarodowych konferencjach i zjazdach. Program ten zasadniczo mi odpowiada”.

Kolejnym problemem dotyczącym prof. Chałasińskiego, o którym pisał W. Puś w „Zarysie...” i mówili socjologowie łódzcy na sympatycznym spotkaniu upamiętniającym 50 lat Wydziału Ekonomiczno-Socjologicznego, jest krytyka przedwojennej twórczości Chałasińskiego dokonana w trudnych latach stalinowskich. Tej krytyki dokonał sam autor. „...Przeprowadził krytykę własnych zasad teoretyczno-metodologicznych, w tym również przejętych od swojego mistrza F. Znanieckiego" - napisał W. Puś. Krytyka w tamtych latach tego, co napisano i pisano przed wojną, była zjawiskiem powszechnym. Oryginalne było to, że w tym przypadku krytykował sam autor, a odosobnione, ale i bezcenne jest to, że Chałasiński miał własne zasady teoretyczno-metodologiczne. One były zbieżne z filozofią i socjologiczną teorią Floriana Znanieckiego. Wiem z bezpośredniej rozmowy z prof. Chałasińskim, że Znaniecki z Ameryki uważnie śledził 
sytuację humanistyki polskiej po 1945 roku i to on właśnie był inicjatorem krytyki „Młodego pokolenia chłopów”. „Jeśli to musi być publicznie skrytykowane, to zrób to sam” - miał napisać Znaniecki i było to jednocześnie upoważnieniem do krytyki filozoficzno-socjologicznej myśli Znanieckiego. Kto ciekawy jaka to była metoda krytyki, niech sięgnie do „Myśli filozoficznej” z 1952 roku. A kto powątpiewa w lojalność metodologiczną Chałasińskiego wobec Znanieckiego, może sięgnąć do dzieł, które powstały i pozostały w światowej i w polskiej socjologii: pięciotomowe dzieło „Chłop polski w Europie i Ameryce” (LSW 1976 - przekład „The Polish peasant In Europe and America” Williama J. Thomasa i Floriana Znanieckiego, które w pierwszym wydaniu ukazało się w Ameryce w l. 1918-1920, w 1968 r. przetłumaczone na język włoski); czterotomowe „Młode pokolenie chłopów” z 1938 r. J. Chałasińskiego; dziesięciotomowa seria pod redakcją J. Chałasińskiego pt. „Młode pokolenie wsi Polski Ludowej” wydawanej przez LSW od 1964 r. Te tomy wraz z innymi monografiami dają bogaty obraz kultury chłopskiej na przestrzeni dwóch wieków. Do tych źródeł sięgają wspominani przeze mnie twórcy różnych dziedzin kultury. W amerykańskim środowisku socjologicznym Chałasiński zyskał miano „Napoleona socjologii polskiej”.

W latach sześćdziesiątych Chałasiński, odsunięty przez władze od uniwersytetu i od studentów, kierował pracownią badań nad kulturą współczesnej Afryki w Polskiej Akademii Nauk. Socjolodzy ironizują, że Profesor nigdy nie był w Afryce, a „Przegląd Socjologiczny” zapełniał artykułami o Afryce. W tym kontekście afrykańskim przypomnę, że Chałasiński wielokrotnie pisał, że literatura piękna jest znakomitą inspiracją i źródłem refleksji socjologicznej, a zapytany kiedyś o pozazawodowe zainteresowania, wymienił twórczość J. Conrada. „Jądro ciemności” Conrada inspirowało badania afrykańskie Profesora. Pierwszy rozdział książki „Bliżej Afryki” - Józefa i Krystyny Chałasińskich zatytułowany „Afryka współczesna i kryzys świadomości europejskiej” zawiera podtytuł: „Jądro ciemności Józefa Conrada - świat nie jest już biały...”. Są to studia nad biografiami intelektualistów i polityków afrykańskich z różnych jej części i stref językowych. To książka o dramacie kształtowania osobowości Afrykanina w konfrontacji ze światem białych. Chałasiński podzielał pogląd amerykańskiego tygodnika z 1960 r., że „ciemność nie leży w sercu Afryki - ona leży w sercu samego cywilizowanego człowieka”. Fascynacja twórczością J. Conrada i sytuowanie socjologii na granicy sztuki sprawiły, że Chałasiński znajdował wspólną perspektywę humanistyczną w obszarach odległych historycznie i przestrzennie. Było nią wyzwalanie się jednostki ze stanowych i środowiskowych uwarunkowań i podmiotowe sytuowanie się we wspólnocie kultury nazywanej przez Profesora związkiem ludzi honoru.

Dla tych historyków i socjologów, którzy uważają twórczość Chałasińskiego za przebrzmiałą, bo nieprzystającą do „ponowoczesności”, proponuję wypowiedź polemiczną z Witoldem Gadomskim młodego socjologa i kulturoznawcy z Uniwersytetu Jagiellońskiego, ur. 1976 r. - Jana Sowy. (GW 13-14.02.2016): „Skoro jest tak świetnie - skąd sukces prawicowego populizmu? Aby poradzić sobie z PiS-em musimy zrozumieć skąd się ta formacja wzięła i co jest kołem zamachowym jej sukcesu. Nie uda się to bez analizy klasowej. Ta zaś została 
w Polsce po 1989 roku wytępiona. Ze statystyk można się dowiedzieć, jak głosowali młodzi, starzy, miasta, wsie itp., ale już nie tego, kogo wybrali biedni, a kogo bogaci. Kto wygrał ostatnie wybory w kategorii ludzi zarabiających rocznie ponad 100 tysięcy zł? A kto wśród 17\% żyjących poniżej minimum socjalnego?

Niszczenie lewicy i analizy klasowej jest niebezpieczne. Obróci się przeciw wartościom liberalnym w o wiele gorszy sposób niż ewentualna redystrybucja. Już się obraca, tzw. Zachód włożył wielki wysiłek w rugowanie od lat siedemdziesiątych laickiej lewicy w krajach islamskich. Wyhodował przez to gorszego potwora: religijny fundamentalizm, który zagarnął cały impet społecznego niezadowolenia. (W kwietniu b.r. Prezydent Obama przyznał, że błędem było obalenie rządu Kadafiego - wtrącenie L.O.)

Z czymś podobnym, z zachowaniem proporcji, mamy do czynienia w Polsce. Stoimy więc przed dylematem znanym z historii: socjalizm albo barbarzyństwo".

Łódź, maj 2016 r.

\section{Leszek Orłowski}

(absolwent socjologii UŁ)

Łódź

Odpowiedź prof. dr. hab. Wiesława Pusia w kolejnym tomie „Zeszytów Wiejskich” (red.). 